\title{
KEPUASAN KERJA DAN EFIKASI GURU TINGKATAN ENAM DI PANTAI BARAT SABAH
}

\section{FORM SIXTH TEACHER JOB SATISFACTION AND EFFICACY IN WEST COAST OF SABAH}

\author{
Ling Lin ${ }^{1}$ \\ Unit Penyelidikan Pendidikan Luar Bandar, Universiti Malaysia Sabah, Malaysia. \\ Mohamad Nizam Bin Nazarudin ${ }^{2}$ \\ Unit Penyelidikan Pendidikan Luar Bandar, Universiti Malaysia Sabah, Malaysia \\ (Email: drnizam.ums@gmail.com) \\ Zakiah Binti Noordin ${ }^{3}$ \\ Institut Pendidikan Guru Kampus Gaya, Sabah, Malaysia.
}

Received date: $24-04-2019$

Revised date: 03-07-2019

Accepted date: $23-07-2019$

Published date: 12-09-2019

To cite this document: Ling, L., Nazarudin, M. N., \& Noordin, Z. (2019). Kepuasan Kerja dan Efikasi Guru Tingkatan Enam di Pantai Barat Sabah. International Journal of Education, Psychology and Counseling, 4 (32), 51-66.

DOI: $10.35631 / \mathrm{IJEPC} .432006$

\begin{abstract}
Abstrak: Kajian ini bertujuan bagi menentukan hubungan dan pengaruh kepuasan kerja terhadap efikasi guru-guru tingkatan enam di Pantai Barat Sabah. Kajian kuantitatif ini adalah bagi turut meninjau interaksi antara dimensi-dimensi dalam kepuasan kerja dan efikasi guru. Instrumen yang terlibat dalam kajian ini adalah Job Satisfaction Survey (JSS) dan Teachers's Sense of Efficacy Scale (TSES) bagi mengumpul data daripada 180 responden daripada 16 buah pusat tingkatan enam di tiga daeah di Pantai Barat Sabah. Persampelan rawak berlapis bertujuan digunakan dalam pemilihan responden dalam kalangan guru akademik tingkatan enam berdasarkan mod. Data dianalisis menggunakan ANOVA satu hala, korelasi Pearson dan regresi berganda. Dapatan kajian menunjukkan tidak terdapat perbezaan yang signifikan kepuasan kerja dan efikasi guru dalam ketiga-ketiga mod pusat tingkatan enam. Analisis korelasi Pearson mendapati terdapat hubungan yang kuat antara kepuasan kerja dengan efikasi guru $\left(\mathrm{r}=.832^{* *}, \mathrm{p}<.01\right)$. Kepuasan kerja menyumbang sebanyak $85.6 \%$ perubahan varians dalam efikasi guru. Justeru, implikasi kajian terhadap teori dan amalan serta saranan kepada pihak sekolah, pembuat dasar dan cadangan kajian lanjutan dicadangkan dalam kajian ini.
\end{abstract}

Kata Kunci: Kepuasan Kerja, Efikasi, Guru Tingkatan Enam

Abstract: This study aims to determine the relationship between job satisfaction and influence on the efficacy form sixth teachers in the West Coast of Sabah. This Quantitative research also surveyed the interaction between the dimensions of job satisfaction and teacher efficacy. The instruments involved in this study is Job Satisfaction Survey (JSS) and Teacher's Sense of 
Efficacy Scale (SES) to collect data from 180 respondents from 16 centres in three districts of West Coast of Sabah. Stratified random sampling been used in the selection of respondents among form sixth teachers based on modes. Data were analyzed using one-way ANOVA, Pearson correlation and multiple regressions. The results showed no significant difference in job satisfaction and efficacy of teachers in the three modes of form sixth centre. Pearson correlation analysis found a strong correlation between job satisfaction and teacher efficacy $(r=.832 * *, p<.01)$. Job satisfaction accounted for $85.6 \%$ changes in the variance in teacher efficacy. Thus, the implications for the theory and practice as well as recommendations to the school authorities, policy makers, and further study is proposed in this study.

Keywords: Job Satisfaction, Efficacy, Form Sixth Teacher

\section{Pengenalan}

Pendidikan ialah penyumbang utama pembangunan modal sosial dan ekonomi negara. Oleh itu, tidak menghairankan sekiranya negara yang mempunyai rakyat berpendidikan tinggi akan berpeluang menikmati kemajuan ekonomi yang lebih tinggi. Pendidikan juga merupakan pencetus kreativiti dan penjana inovasi yang melengkapkan generasi muda dengan kemahiran yang diperlukan untuk bersaing dalam pasaran kerja, dan menjadi pengupaya perkembangan ekonomi keseluruhannya. Pendidikan menyediakan peluang kepada individu untuk meningkatkan taraf hidup, menjadi ahli masyarakat yang berjaya dan menyumbang secara aktif kepada pembangunan negara. Sehubungan dengan itu, kerajaan perlu memastikan sistem pendidikan negara berfungsi secara berkesan untuk menjayakan Model Baru Ekonomi, Program Transformasi Ekonomi dan Program Transformasi Kerajaan yang menjadi asas perkembangan ekonomi negara dalam persaingan ekonomi global. Sistem pendidikan kita merupakan tunjang pembangunan negara. Transformasi Tingkatan Enam telah dilaksanakan mulai tahun 2013 bagi memenuhi hasrat yang terkandung dalam Pelan Pembangunan Pendidikan Malaysia (PPPM) 2013-2015.

Sehubungan dengan itu, Bahagian Pengurusan Sekolah Harian Yang dipertanggungjawabkan dalam aspek pengoperasian Tingkatan Enam telah mengambil inisiatif untuk menerbitkan Garis Panduan Pengurusan Tingkatan Enam (GPPT6) bagi membantu pihak sekolah untuk memantapkan pengurusan dan pentadbiran Tingkatan Enam. GPPT6 mengandungi tujuh bab iaitu latar belakang, pengurusan dan pentadbiran, pengurusan akademik, pengurusan kokurikulum, pengurusan sumber manusia (guru), pengurusan murid, dan pengurusan peperiksaan serta pentaksiran STPM. Penambahbaikan GPPT6 juga telah dibentangkan dalam Mesyuarat Pengurusan Tertinggi. Kementerian Pendidikan Malaysia bagi memastikan keberhasilan GPPT6 dapat memenuhi aspirasi PPPM 2013-2025.

Secara keseluruhannya, hasrat ini mesti dicapai melalui pengagihan sumber yang terancang dan teliti dan seterusnya memastikan setiap ringgit dibelanjakan untuk meningkatkan keberhasilan dan kemenjadian murid. Kementerian Pendidikan Malaysia bertekad untuk meningkatkan pencapaian murid dengan menyediakan sistem pendidikan yang efisien. Peningkatan kualiti, ekuiti dan akses dalam pendidikan akan terus diperkukuh untuk memastikan kelangsungan kejayaan yang telah dicapai sejak negara mencapai kemerdekaan. Pelaksanaan pengajian tingkatan enam sebagai prauniversiti berwajah baru baharu masih dalam proses peralihan. Hanya kohort pelajar tingkatan enam rendah tahun 2011 bakal menjalani sepenuhnya sistem baharu yang membabitkan perubahan dasar besar-besaran dari segi kurikulum, penyampaian, pentafsiran dan aktiviti nilai tambah yang lain. Persiapan dari segi kelengkapan pembelajaran, modul dan tenaga guru akademik (pensyarah) juga 
memerlukan masa untuk dimobilisasikan. Ketua Pengarah Pelajaran Malaysia, Tan Sri Alimuddin begitu prihatin terhadap sistem pengajian tingkatan enam yang semakin dicabar hebat oleh kemunculan sistem pengajian prauniversiti yang lain. Jika hendak menunggu segalagalahnya sempurna baru hendak dilaksanakan, barangkali peluang kenaikan pangkat guru akademik tingkatan enam dan sistem pengajian tingkatan enam sedia ada akan semakin terpinggir daripada arus perdana pendidikan tinggi.

Pelaksanaan penjenamaan tingkatan enam berpunca daripada isu murid kurang minat ke tingkatan enam, murid beranggapan pendidikan tingkatan enam sukar, pendidikan tingkatan enam bukan pilihan ibubapa dan murid serta kebanyakan guru tingkatan enam dikehendaki mengajar arus perdana di samping mengajar tingkatan enam. Terdapat lima fokus dalam penjenamaan tingkatan enam ialah imej dan anjakan minda, pengurusan dan pentadbiran, kurikulum dan info \& infra-struktur serta mod pengajaran dan pembelajaran ( $\mathrm{PdP})$.

\section{Masalah Kajian}

Garis Panduan Pengurusan Tingkatan Enam (2016) menerangkan fokus info dan infrastruktur iaitu cadangan perlaksanaan terbahagi kepada Mod 1, Mod 2 dan Mod 3. Pelaksanaan Mod 1 berasingan dengan sekolah arus perdana, pentadbiran dan bangunan tersendiri, beroperasi dengan bilangan kelas sekurang-kurangnya 12 kelas, Mod 2 bagi sekolah menengah kebangsaan (SMK) tingkatan satu aliran perdana ditutup secara beransur-ansur, membaik pulih bilik darjah, makmal dan asrama jika perlu, berkongsi dengan sekolah arus perdana, penggunaan blok berasingan, menggabungkan kelas tingkatan enam dari SMK berhampiran. Mod 3 berkongsi dengan sekolah arus perdana di luar bandar, kurang kemudahan pengangkutan awam dan asrama, penggunaan blok berasingan, di bawah pentadbiran pengetua sekolah sedia ada, kurang daripada 12 kelas, beroperasi dengan bilangan kelas sedia ada, membaik pulih bilik darjah, makmal dan asrama jika perlu.

Fokus pengurusan dan pentadbiran iaitu pengekalan jawatan guru dan staf, guru tingkatan enam yang tersendiri, pengenalan struktur baharu tingkatan enam, membina laluan kerjaya guru, penyediaan peralatan sekolah, memperhebat promosi tingkatan enam, penggunaan norma perjawatan guru tingkatan enam sedia ada, guru tingkatan enam mengajar tingkatan enam sahaja dan mengikut opsyen yang diperlukan, penyemakan gred perjawatan guru tingkatan enam sedia ada, pengenalan laluan guru cemerlang tingkatan enam, penempatan guru tingkatan enam sedia ada ke Pusat Tingkatan Enam menggunakan struktur pentadbiran baharu, guru tingkatan enam boleh ditempatkan atau berpindah ke kolej matrikulasi, institusi pendidikan guru (IPG) atau laluan pengurusan Kementerian Pelajaran Malaysia (KPM), penubuhan unit tingkatan enam berserta perjawatan di jabatan pelajaran negeri dan pejabat pelajaran daerah, melengkapkan peralatan mengikut keperluan PdP murid tingkatan enam, promosi tingkatan enam kepada awam melalui semua peringkat KPM dan pelbagai media.

Dari aspek info dan infra struktur, pusat tingkatan enam Mod 1 lebih baik berbanding dengan pusat tingkatan enam Mod 2 dan Mod. Infra struktur pusat tingkatan enam Mod 1 adalah berasingan daripada arus perdana dan mempunyai pentadbiran dan bangunan tersendiri. Mod 1 akan beroperasi dengan menggunakan PIB dan bagi menggunakan SMK kelas tingkatan satu aliran perdana ditutup secara beransur-ansur. Manakala Mod 2 pula, berkongsi dengan sekolah perdana tetapi penggunaan blok yang berasingan. Pusat tingkatan enam Mod 2 berada di bawah pentadbiran pengetua sekolah sedia ada. Di samping itu, pelaksanaan Mod 2 akan menggabungkan kelas tingkatan enam dari SMK yang berhampiran. Untuk pusat tingkatan enam Mod 3 berkongsi dengan sekolah arus perdana di luar bandar, kurang kemudahan pengangkutan awam dan asrama. Mod 3 terpaksa berkongsi blok dengan arus perdana dan 
berada di bawah pentadbiran pengetua sekolah sedia ada. Maka dari segi infa struktur, pusat tingkatan enam Mod 1 adalah lebih selesa dan sempurna berbanding dengan mod yang lain. Persekitaran kerja akan mempengaruhi kepuasan kerja. Persekitaran kerja berkait langsung dengan iklim sekolah yang diwujudkan melalui sistem pengurusan dan pentadbiran organisasi. Keadaan fizikal kerja yang tidak memuaskan juga boleh menjejaskan prestasi kerja seseorang.

Justeru itu, kajian ini dilakukan untuk mengkaji sama ada kemimpinan pengetua, profesionalisme guru, tekanan pencapaian murid dan penglibatan masyarakat mewujudkan iklim sekolah yang kondusif. Selain itu, penyelidik ingin mengenal pasti tahap efikasi guru dari aspek penglibatan murid, strategi pengajaran dan pengurusan kelas dalam kalangan guru akademik tingkatan enam. Kajian ini juga mengenal pasti hubungan antara iklim sekolah dan efikasi guru serta meninjau pengaruh iklim sekolah ke atas efikasi guru dalam kalangan guru akademik tingkatan enam di Pantai Barat Sabah.

\section{Objektif Kajian}

Secara khususnya, objektif bagi kajian ini adalah seperti yang berikut:

1. Mengenal pasti tahap kepuasan kerja dan efikasi guru dalam kalangan guru akademik tingkatan enam berdasarkan mod.

2. Mengenal pasti perbezaan tahap kepuasan kerja dan efikasi guru dalam kalangan guru akademik tingkatan enam berdasarkan mod.

3. Mengenal pasti hubungan antara kepuasan kerja dengan efikasi guru dalam kalangan guru akademik tingkatan enam.

4. Mengenal pasti pengaruh kepuasan kerja ke atas efikasi guru akademik tingkatan enam.

\section{Hipotesis Kajian}

Hipotesis dalam kajian ini adalah seperti berikut:

Ho$_{1}$ : Tidak terdapat perbezaan yang signifikan dalam skor min kepuasan kerja dalam kalangan guru akademik tingkatan enam berdasarkan mod;

Ho2: Tidak terdapat perbezaan yang signifikan dalam skor min efikasi guru dalam kalangan guru akademik tingkatan enam berdasarkan mod;

Ho3: Tidak terdapat hubungan yang signifikan antara kepuasan kerja dengan efikasi guru dalam kalangan guru akademik tingkatan enam;

Ho4: Tidak terdapat pengaruh yang signifikan antara kepuasan kerja dengan efikasi guru dalam kalangan guru akademik tingkatan enam;

\section{Metodologi Kajian}

Instrumen yang terlibat dalam kajian ini adalah Job Satisfaction Survey (JSS) dan Teachers's Sense of Efficacy Scale (TSES) bagi mengumpul data daripada 180 responden yang telah melengkapkan borang soal selidik daripada 16 buah pusat tingkata enam di tiga daeah di Pantai Barat Sabah. Persampelan rawak berlapis bertujuan digunakan dalam pemilihan responden dalam kalangan guru akademik tingkatan enam berdasarkan mod. Data inferensi dianalisis menggunakan ANOVA satu hala, korelasi Pearson dan regresi berganda.

\section{Dapatan Kajian}

\section{Taburan Normaliti Data Kajian}

Berdasarkan Jadual 1 Keputusan ujian normaliti bagi nilai skewness dan kurtosis variabel kepuasan kerja ialah -.016 dan -.499. Nilai skewness (.114) dan kurtosis (.045) bagi efikasi guru yang berada dalam julat -1.00 hingga +1.00 juga menunjukkan bahawa taburan data adalah normal berdasarkan kriteria Sheridan (2013). 
Jadual 1: Taburan Normaliti Data Kajian

\begin{tabular}{ccccccc}
\hline $\begin{array}{c}\text { Pemboleh } \\
\text { Ubah Kajian }\end{array}$ & Min & SD & Skewness & Kurtosis & $\begin{array}{c}\text { Kolmogorov- } \\
\text { smirnov }\end{array}$ & $\begin{array}{c}\text { Shapir } \\
\text { o-wilk }\end{array}$ \\
\hline $\begin{array}{c}\text { Kepuasan } \\
\text { Kerja }\end{array}$ & 160.872 & $\begin{array}{c}18.93 \\
4\end{array}$ & -.016 & -.499 & $.200^{*}$ & .45 \\
\hline Efikasi guru & 85.022 & $\begin{array}{c}10.82 \\
6\end{array}$ & .114 & .045 & $.200^{*}$ & .775 \\
\hline
\end{tabular}

Ciri Demografi Responden

Berdasarkan Jadual 2 menunjukkan profil responden berdasarkan demografi jantina didapati daripada 180 responden kajian.

Jadual 2: Taburan Responden Mengikut Ciri Demografi

\begin{tabular}{lccc}
\hline Bil & Demografi & Sampel (N-180) & Peratus (\%) \\
\hline 1. & Jantina & 62 & 34.44 \\
& perempuan & 118 & 65.56 \\
\hline 2. & Mod 1 & 40 & 22.22 \\
& Mod 2 & 36 & 20.00 \\
& Mod 3 & 104 & 57.78 \\
\hline 3. & PPD Kota Kinabalu & 106 & 58.89 \\
& PPD Penampang & 36 & 20.00 \\
& PPD Tuaran & 38 & 21.11 \\
\hline
\end{tabular}

\section{Kebolehpercayaan Instrumen Kajian}

Jadual 3 menunjukan Koefisien kebolehpercayaan Alfa Cronbach bagi soal selidik kepuasan kerja adalah 0.889 dan efikasi guru adalah adalah 0.915 yang dianggap dianggap tinggi dan boleh diterima diguna pakai untuk kajian sebenar yang meninjau iklim sekolah dan efikasi guru di pusat-pusat tingkatan enam di Pantai Barat Sabah.

Jadual 3: Kebolehpercayaan Instrumen Kajian

\begin{tabular}{cccc}
\hline Instrumen & Cronbach's Alpha & $\begin{array}{c}\text { Cronbach's Alpha } \\
\text { Based on } \\
\text { Standardized Items }\end{array}$ & N of items \\
\hline Kepuasan kerja & .889 & .892 & 36 \\
\hline Efikasi Guru & .915 & .920 & 12 \\
\hline
\end{tabular}

\section{Tahap Kepuasan Kerja}

Bagi soal selidik tentang kepuasan kerja yang mengandungi 36 pernyataan item telah dijawab oleh responden berdasarkan persepsi mereka terhadap sembilan dimensi. Pemboleh ubah kepuasan kerja terdiri daripada sembilan dimensi iaitu upah, kenaikan pangkat, penyeliaan, faedah bukan berbentuk kewangan, penghargaan yang tidak dijangka, operasi prosedur, rakan sejawat, persekitaran kerja dan komunikasi. Merujuk kepada Jadual 4 keputusan keseluruhan kepuasan kerja bagi ketiga-tiga mod pusat tingkatan enam pada aras yang tinggi.

Jadual 4: Tahap Kepuasan Kerja

\begin{tabular}{ccccc}
\hline Kepuasan & $\mathbf{N}$ & Min & SP & Tahap \\
Kerja & 180 & 4.4693 & .52544 & Tinggi \\
\hline
\end{tabular}


Jadual 5 menunjukkan aras taburan kepuasan kerja secara keseluruhan didapati bahawa purata skor min kepuasan kerja ialah 4.4693 dan sisihan piawai .52544. Purata skor min ini menunjukkan bahawa kepuasan kerja berada pada aras yang tinggi. Keputusan analisis menunjukkan skor min mod 1 tertinggi (4.5875), diikuti oleh mod 2 (4.4753) manakalan skor min yang terendah ialah mod 3 (4.4218) berbanding dengan mod pusat tingkatan enam yang lain. Dapatan nilai sisihan piawai menunjukkan taburan data kepuasan kerja berada pada pola serakan yang tidak jauh berbeza dan seragam.

Jadual 5: Tahap Kepuasan Kerja Mengikut Mod

\begin{tabular}{ccccc}
\hline Mod & N & Min & SP & Tahap \\
\hline Mod 1 & 40 & 4.5875 & .48780 & Tinggi \\
Mod 2 & 36 & 4.4753 & .54683 & Tinggi \\
Mod 3 & 104 & 4.4218 & .52951 & Tinggi \\
\hline
\end{tabular}

\section{Tahap Efikasi Guru}

Terdapat 12 pernyataan yang menjelaskan tentang efikasi guru dan terbahagi kepada tiga dimensi iaitu penglibatan murid, strategi pengajaran dan pengurusan kelas. Berdasarkan Jadual 6, didapati bahawa secara keseluruhan aras tahuran efikasi guru adalah tinggi dalam ketigatiga mod.

Jadual 6: Tahap Efikasi Guru

\begin{tabular}{ccccc}
\hline \multirow{2}{*}{ Efikasi guru } & $\mathbf{N}$ & Min & SP & Tahap \\
\cline { 2 - 5 } & 180 & 7.0889 & .90457 & Tinggi \\
\hline
\end{tabular}

\section{Tahap Efikasi Guru Mengikut Mod}

Jadual 7 menunjukkan aras efikasi guru di pusat-pusat tingkatan enam di Pantai Barat Sabah secara keseluruhan adalah tinggi dan seragam mengikut mod. Hasil analisis deskriptif menunjukkan aras taburan efikasi guru secara keseluruhan didapati bahawa purata skor min ini menunjukkan bahawa efikasi guru berada pada aras yang tinggi. Keputusan analisis menunjukkan skor min mod 1 tertinggi (7.1875), diikuti oleh mod 3 (7.0753) manakalan skor min yang terendah ialah mod 2 (7.0185) berbanding dengan mod pusat tingkatan enam yang lain.

Jadual 7: Tahap Efikasi Guru Mengikut Mod

\begin{tabular}{ccccc}
\hline Mod & N & Min & SP & Tahap \\
\hline Mod 1 & 40 & 7.1875 & .70148 & Tinggi \\
Mod 2 & 36 & 7.0185 & .95849 & Tinggi \\
Mod 3 & 104 & 7.0753 & .95803 & Tinggi \\
\hline
\end{tabular}

\section{Perbezaan Kepuasan Kerja Berdasarkan Mod}

Berdasarkan Jadual 8, analisis ujian menunjukkan nilai signifikan ialah $\mathrm{p}=.578,(\mathrm{~F}=.549)$ iaitu lebih besar daripada nilai siginifikan yang ditetapkan $(\mathrm{p}<.05)$. Dengan ini, hipotesis Ho1 diterima iaitu tidak terdapat perbezaan antara keselarasan kepuasan kerja berdasarkan mod tingkatan enam. 
Jadual 8: Analisis ANOVA Satu Hala Kepuasan Kerja Berdasarkan Mod

\begin{tabular}{llccccc}
\hline $\begin{array}{c}\text { Pemboleh } \\
\text { ubah }\end{array}$ & \multicolumn{1}{c}{ Mod } & ss & df & $\begin{array}{c}\text { Min } \\
\text { Square }\end{array}$ & F & Sig. \\
\hline Kepuasan & Dalam Kumpulan & .251 & 2 & .125 & .549 & .578 \\
Kerja & Antara Kumpulan & 40.433 & 117 & .228 & & \\
& Jumlah & 40.684 & 119 & & & \\
\hline
\end{tabular}

Analisis ANOVA Satu Hala Perbezaan Skor Min Efikasi Guru Berdasarkan Mod Jadual 9, menunjukkan nilai signifikan ialah $\mathrm{p}=.701$, $(\mathrm{F}=.356)$ iaitu lebih besar daripada nilai signifikan yang ditetapkan $(\mathrm{p}<.05)$. Dengan ini, hipotesis $\mathrm{Ho}_{2}$ diterima iaitu tidak terdapat perbezaan antara efikasi guru berdasarkan mod.

Jadual 9: Analisis ANOVA Satu Hala Efikasi Guru Berdasarkan Mod

\begin{tabular}{lllllll}
\hline Pemboleh ubah & & SS & df & $\begin{array}{l}\text { Min } \\
\text { Square }\end{array}$ & F & Sig. \\
\hline Penglibatan & Dalam Kumpulan & .190 & 2 & .095 & .109 & .879 \\
& Antara Kumpulan & 154.288 & 177 & .877 & & \\
& Jumlah & 154.478 & 179 & & & \\
\hline Strategi & Dalam Kumpulan & 2.491 & 2 & 1.246 & 1.319 & .270 \\
Pengajaran & Antara Kumpulan & 167.195 & 177 & .945 & & \\
& Jumlah & 169.686 & 179 & & & \\
\hline Pengurusan & Dalam Kumpulan & 2.389 & 2 & 1.195 & 1.084 & .340 \\
Kelas & Antara Kumpulan & 195.031 & 177 & 1.102 & & \\
& Jumlah & 197.420 & 179 & & & \\
\hline Efikasi Guru & Dalam Kumpulan & .586 & 2 & .293 & .356 & .701 \\
& Antara Kumpulan & 145.880 & 177 & .824 & & \\
& Jumlah & 146.467 & 179 & & & \\
\hline
\end{tabular}

\section{Hubungan Antara Kepuasan Kerja dan Efikasi Guru}

Analisis korelasi Pearson seperti dalam Jadual 10 menunjukkan aras hubungan bagi dimensidimensi dalam kepuasan kerja iaitu upah, kenaikan pangkat, penyeliaan, faedah bukan berbentuk kewangan, penghargaan yang tidak dijangka ,operasi prosedur, rakan sejawat, persekitaran kerja, dan komunikasi dengan dimensi-dimensi efikasi guru iaitu penglibatan pelajar, strategi pengajaran dan pengurusan kelas. Keputusan analisis korelasi menunjukkan semua konstruk dan dimensi mempunyai hubungan positif yang kuat. Terdapat hubungan skor min yang signifikan antara kepuasan kerja dengan efikasi guru $(\mathrm{r}=.832 * *, \mathrm{p}<.01)$. Oleh itu, hipotesis nol yang mengatakan tidak terdapat hubungan signifikan antara kepuasan kerja dengan efikasi guru adalah ditolak. Hasil daripada kajian ini menunjukkan terdapat hubungan signifikan positif iaitu semakin tinggi kepuasan kerja maka semakin tinggi aras efikasi guru. Secara keseluruhan, hubungan konstruk kepuasan kerja dan dimensi-dimensinya dengan konstruk efikasi guru adalah kuat dan signifikan.

Jadual 10: Korelasi Pearson $r$ Antara Kepuasan Kerja dan Efikasi Guru

\begin{tabular}{cccccc}
\hline Pemboleh ubah & \multicolumn{2}{c}{$\begin{array}{c}\text { Penglibatan } \\
\text { Murid }\end{array}$} & $\begin{array}{c}\text { Strategi } \\
\text { Pengajaran }\end{array}$ & $\begin{array}{c}\text { Pengurusan } \\
\text { Kelas }\end{array}$ & $\begin{array}{c}\text { Efikasi } \\
\text { Guru }\end{array}$ \\
\hline Kepuasan kerja & $\begin{array}{c}\text { Pearson } \\
\text { Correlation } \\
\text { Sig. }(2-\end{array}$ & $.787 *$ & $.722^{*}$ & $.724 *$ & $.832 *$ \\
& $\begin{array}{c}\text { tailed) } \\
\text { taile }\end{array}$ & .030 & .030 & .030 & .036 \\
\hline
\end{tabular}




\begin{tabular}{|c|c|c|c|c|c|}
\hline Upah & $\begin{array}{c}\text { Pearson } \\
\text { Correlation } \\
\text { Sig. (2- } \\
\text { tailed) }\end{array}$ & $\begin{array}{l}.742 * \\
.034\end{array}$ & $\begin{array}{l}.749 * \\
.012\end{array}$ & $\begin{array}{l}.699 * \\
.035\end{array}$ & $\begin{array}{c}.780 * \\
.028\end{array}$ \\
\hline Kenaikan Pangkat & $\begin{array}{c}\text { Pearson } \\
\text { Correlation } \\
\text { Sig. (2- } \\
\text { tailed) }\end{array}$ & $\begin{array}{c}.776^{*} \\
.018\end{array}$ & $\begin{array}{c}.701 * \\
.017\end{array}$ & $\begin{array}{l}.774 * \\
.020\end{array}$ & $\begin{array}{c}.776^{*} \\
.018\end{array}$ \\
\hline Penyeliaan & $\begin{array}{c}\text { Pearson } \\
\text { Correlation } \\
\text { Sig. (2- } \\
\text { tailed) }\end{array}$ & $\begin{array}{l}.721 * \\
.300\end{array}$ & $\begin{array}{l}.704^{*} \\
.014\end{array}$ & $\begin{array}{l}.799 * \\
.018\end{array}$ & $\begin{array}{c}.799 * \\
.018\end{array}$ \\
\hline $\begin{array}{c}\text { Faedah bukan } \\
\text { berbentuk } \\
\text { kewangan }\end{array}$ & $\begin{array}{c}\text { Pearson } \\
\text { Correlation } \\
\text { Sig. (2- } \\
\text { tailed) }\end{array}$ & $\begin{array}{c}.718 * \\
.015\end{array}$ & $\begin{array}{c}.728 * \\
.029\end{array}$ & $\begin{array}{c}.716^{*} \\
.034\end{array}$ & $\begin{array}{c}.810^{*} \\
.046\end{array}$ \\
\hline $\begin{array}{l}\text { Penghargaan yang } \\
\text { tidak dijangka }\end{array}$ & $\begin{array}{c}\text { Pearson } \\
\text { Correlation } \\
\text { Sig. (2- } \\
\text { tailed) }\end{array}$ & $\begin{array}{l}.734 * \\
.042\end{array}$ & $\begin{array}{l}.749 * \\
.014\end{array}$ & $\begin{array}{l}.716^{*} \\
.035\end{array}$ & $\begin{array}{c}.810^{*} \\
.034\end{array}$ \\
\hline Operasi Prosedur & $\begin{array}{c}\text { Pearson } \\
\text { Correlation } \\
\text { Sig. (2- } \\
\text { tailed) }\end{array}$ & $\begin{array}{l}.710^{*} \\
.038\end{array}$ & $\begin{array}{l}.768^{*} \\
.036\end{array}$ & $\begin{array}{l}.725^{*} \\
.039\end{array}$ & $\begin{array}{c}.719^{*} \\
.037\end{array}$ \\
\hline Rakan Sejawat & $\begin{array}{l}\text { Pearson } \\
\text { Correlation } \\
\text { Sig. (2- } \\
\text { tailed) }\end{array}$ & $\begin{array}{l}.741^{*} \\
.013\end{array}$ & $\begin{array}{l}.792^{*} \\
.017\end{array}$ & $\begin{array}{l}.740 * \\
.031\end{array}$ & $\begin{array}{c}.723 * \\
.101\end{array}$ \\
\hline Persekitaran Kerja & $\begin{array}{c}\text { Pearson } \\
\text { Correlation } \\
\text { Sig. (2- } \\
\text { tailed) }\end{array}$ & $\begin{array}{l}.783^{*} \\
.014\end{array}$ & $\begin{array}{l}.207 * * \\
.005\end{array}$ & $\begin{array}{l}.184^{*} \\
.013\end{array}$ & $\begin{array}{l}.800 * * \\
.007\end{array}$ \\
\hline Komunikasi & $\begin{array}{l}\text { Pearson } \\
\text { Correlation } \\
\text { Sig. (2- } \\
\text { tailed) }\end{array}$ & $\begin{array}{l}.708^{*} \\
.039\end{array}$ & $\begin{array}{c}.710 * * \\
.005\end{array}$ & $\begin{array}{c}.714^{*} \\
.017\end{array}$ & $\begin{array}{l}.756^{*} \\
.037\end{array}$ \\
\hline
\end{tabular}

Signifikan pada aras $* \mathrm{p}<.05, * * \mathrm{p}<.01$

Pengaruh Kepuasan Kerja Terhadap Efikasi Guru

Berdasarkan kepada analisis jadual 11, regresi prestasi pengadil didapati signifikan dengan pemboleh ubah bebas dengan nilai $\mathrm{F}(1,179)=3.175$, $\mathrm{p}<.05$. Ini menunjukkan model linear regresi sesuai dengan data. 
Jadual 11: Analisis Varians (ANOVA)

\begin{tabular}{lccccc}
\hline Model & $\begin{array}{c}\text { Jumlah } \\
\text { Kuasa Dua } \\
\text { (SS) }\end{array}$ & df & MS & F & Sig. \\
\hline Regrasi & .866 & 1 & .866 & 3.175 & $.016^{\mathrm{b}}$ \\
\hline Residual & 48.554 & 178 & .273 & & \\
\hline Jumlah & 49.420 & 179 & & & \\
\hline
\end{tabular}

Jadual 12 adalah ringkasan model regresi bagi iklim sekolah sebagai pemboleh ubah peramal dengan efikasi guru sebagai pemboleh ubah bersandar. Iklim sekolah (pemboleh ubah tak bersandar) dapat menerangkan sebanyak $85.6 \%\left(\mathrm{R}^{2}=.856\right)$ daripada varians yang wujud dalam

Jadual 12: Ringkasan Model Regresi Kepuasan Kerja Terhadap Efikasi Guru

\begin{tabular}{ccccc}
\hline Model & $\mathbf{R}$ & $\mathbf{R}^{\mathbf{2}}$ & $\mathbf{R}^{\mathbf{2}}$ Terlaras & $\mathbf{S E}$ \\
\hline $\mathbf{1}$ & $.632^{\mathrm{a}}$ & .856 & .812 & .52228 \\
\hline
\end{tabular}

\section{Perbincangan}

\section{Tahap Kepuasan Kerja Guru Akademik Tingkatan Enam Berdasarkan Mod}

Kepuasan kerja adalah antara faktor yang menyumbang terhadap keberkesanan kualiti kerja guru-guru. Peningkatan yang berlaku di dalam kepuasan kerja guru mampu memotivasikan mereka untuk meneruskan usaha bagi meningkatkan kemahiran pengajaran, menjana persekitaran pembelajaran yang lebih baik untuk melonjakkan pencapaian pelajar. Dimensi kepuasan kerja adalah berbeza-beza antara seseorang individu dengan individu yang lain. Kepuasan bekerja guru secara positifnya berkait dengan isu yang sering ditimbulkan di sekolah iaitu profesionalisme guru, penglibatan dalam membuat keputusan, perkembangan guru, keupayaan guru, persepsi tentang iklim sekolah dan suasana tempat bekerja (Quaglia \& Marion, 1991). Seterusnya kuasa autonomi di dalam bilik dajah, sokongan pihak pentadbir, dan peluang untuk memimpin, mempunyai kepentingan di dalam menjelaskan tentang perbezaan peringkat kepuasan bekerja guru (Junaidah Mohamad, 2013). Musfi Erfrizal (2011) mendapati bahawa kepuasan kerja adalah pemboleh ubah yang paling berpengaruh dan dominan terhadap prestasi pekerja berbanding dengan pemboleh ubah yang lain-lain. Hal ini menunjukkan apabila kepuasan kerja tercapai, maka perasaan pekerja terhadap kerjanya juga kan berubah sekali gus menjadikan pekerja lebih bersemangat dalam setiap pekerjaan yang dilakukan dan mempamerkan prestasi kerja yang baik.

Sikap yang positif terhadap kerjanya secara konsepnya boleh dinyatakan setimpal dengan kepuasan kerja dan sikap negatif terhadap kerjanya adalah sama dengan ketidakpuasan. Faktor kepuasan kerja amat penting kepada setiap individu yang bekerja. Apabila wujudnya kepuasan kerja, ianya akan mendorong pekerja meningkatkan prestasi dan produktiviti dan dalam masa yang sama dapat memastikan sasaran sekolah tercapai. Guru-guru yang berpuas hati dengan kerjanya akan menjadi lebih produktif dan memberikan komitmen yang tinggi dalam pekerjaan. Secara keseluruhannya, kajian tahap kepuasan kerja dapat membantu organisasi menggunakannya sebagai rujukan dalam meningkatkan tahap kepuasan kerja terutamanya di kalangan guru untuk merancang sebarang perubahan. Justeru itu, faktor-faktor yang menyebabkan ketidakpuasan kerja mestilah dikenalpasti agar perkara-perkara yang menimbulkan rasa tidak puas hati dapat diatasi untuk kebaikan bersama. 
Kebanyakan kajian tentang kepuasan kerja guru merujuk kepada hasil kerja terawal oleh Herzberg. Kepuasan kerja dan ketidakpuasan kerja adalah saling berkait tetapi dipengaruhi oleh faktor yang berbeza. Teori Dua Faktor Herzberg menggabungkan faktor-faktor kepuasan iaitu motivasi dan faktor ketidakpuasan iaitu hygiene. Tahap motivasi tinggi merangkumi aspek intrinsik iaitu pencapaian, pengiktirafan, pekerjaan, tanggungjawab dan peluang untuk memajukan diri. Manakala faktor ketidakpuasan adalah suasana tempat kerja, penyeliaan, polisi kerja, gaji dan hubungan interpersonal. Hasil kajian memperlihatkan min mengikut mod terhadap kepuasan kerja tidak mempunyai perbezaan skor min yang signifikan. Hal ini berkemungkinan guru-guru akademik tingkatan lebih berpengalaman dalam mengendalikan pelajar serta menerima autoriti daripada rakan sekerja dan pihak atasan, dapat mengadaptasi diri dengan pelajar dan persekitaran kerja serta boleh menjangkakan situasi yang bakal dihadapi pada masa hadapan.

\section{Tahap Efikasi Guru Akademik Tingkatan Enam Berdasarkan Mod}

Dapatan kajian menunjukkan secara keseluruhannya responden mod bagi ketiga-tiga merasakan mereka mempunyai tahap keyakinan tinggi untuk menjayakan tugasan pengajaran yang meliputi keupayaan melibatkan pelajar dalam pembelajaran, membina sistem pengurusan kelas yang mampu dipatuhi oleh semua murid serta berkeupayaan dalam mempratikkan strategi pengajaran baharu serta mempelbagaikan kaedah pentaksiran dalam kelas. Pendapat Bardi dan Schwartz (2003) individu yang mempunyai tahap efikasi rendah didapati mungkin keberatan untuk memulakan dan menyempurnakan tugasan kerja seperti yang diharapkan. Oleh itu, dalam usaha mencapai prestasi yang diinginkan, maka sudah tentunya menuntut agar guru mempunyai tahap efikasi guru yang tinggi. Manakala Stewart et al., (2011) telah membuat analisis secara mendalam mengenai efikasi berdasarkan pandangan pengkaji terdahulu. Mereka menjelaskan bahawa efikasi merujuk kepada justifikasi guru tentang kecekapan dan keupayaan untuk membawa hasil yang bermakna dan signifikan terhadap pencapaian pendidikan untuk semua pelajar. Penekanan terhadap ramuan aspek efikasi guru adalah merupakan faktor yang dapat membezakan antara guru berkesan dengan tidak berkesan. Indikator ini dapat dikenal pasti menerusi keupayaan guru melaksanakan tugas mendidik selaras dengan tingkah laku kepimpinan pengajaran mereka di dalam bilik darjah.

Kajian ini menggunakan instrumen Teacher Sense of Efficacy Scale yang digunakan dalam kedua-dua kajian tersebut, didapati bahawa efikasi berada pada tahap tinggi. Ini bermakna kajian ini menyokong dapatan kedua-dua kajian yang dilakukan oleh Tschannen-Moran dan Hoy (2001) dan (2002). Dapatan ini juga menyamai dapatan kajian yang dilakukan oleh Khalid (2009) yang menggunakan skala Teacher Sense of Efficacy Scale versi 12 bagi menyelidik pola efikasi guru-guru di sabag dan juga dapatan Faridah dan Khalid (2010) yang menggunakan skala Teacher Sense of Efficacy Scale versi 24 bagi mengukur aras efikasi guru sekolah menengah Teknik. Walaupun menggunakan versi yang berbeza tetapi dapatan kajian adalah konsisten walaupun konteks kajiannya berbeza. Ini menunjukkan bahawa efikasi guru sekolahsekolah menengah di Sabah agak konsisten dan mengesahkan keseuaian skala pengurusan TSES sama ada versi 12 ataupun versi 24 untuk digunakan bagi mengukur tahap keyakinan diri guru dalam melaksanakan tugasan mengajar.

Dapatan ini menyokong kenyataan Bandura (1997) dan Tschannen-Moran et al. (1998) yang menyetakan bahawa efikasi guru mempengaruhi kompetensi pengajaran dengan mempengaruhi motivasi mereka. Guru-guru yang berefikasi tingg adalah lebih bersedia untuk mengambil bahagian dalam pengajaran yang mencabar dan produktif berbanding dengan guruguru yang rendah efikasinya. Hasilnya, guru-guru berefikasi tinggi berupaya menyumbang kepada kecemerlangan organisasi sekolah. Sekolah memerlukan guru yang berefikasi tinggi 
yang komited dalam pengajaran, lebih bermotivasi serta berusaha dengan bersungguh-sungguh untuk menunjukkan prestasi yang lebih baik (Maistry \& Parker, 2010). Guru-guru yang mempunyai efikasi yang tinggi tidak mempunyai masalah dalam memberi penjelasan dengan kepelbagaian idea ataupun alternative bagi memudahkan kefahaman pelajar. Guru-guru ini bijak dalam mempelbagaikan aras penyoalan yang dapat mencungkil idea kreatif pelajar serta berkemampuan tinggi menjawab soalan sukar. Pendapat yang sama disuarakan oleh pengkaji ang terdahulu yang menyatakan bahawa guru-guru yang berefikasi tinggi tidak mempunyai masalah untuk meneroka ilmu pedagogi baharu dan mempelbagaikan pendekatan bagi memenuhi keperluan pelajar-pelajar yang jelas berbeza-beza (Cousin \& Walker, 2000). Hal yang sama dilakukan dalam pengurusan kelas dan disiplin pelajar, guru-guru yang berefikasi tinggi mampu mengendalikannya dengan baik.

Efikasi guru adalah isu terpenting dalam bidang pendidikan secara khusus terutama apabila masyarakat mahu meningkatkan kualiti pendidikan dan masa depan generasi dalam jangka masa Panjang. Guru-guru yang percaya kepada kemampuan diri dalam melaksanakan tugasan pengajaran dan pembelajaran menjadi idola pelajar. Nilai positif yang ditunjukkan oleh guruguru tersebut menjadi kayu ukuran kepada pencapaian kejayaan mereka di masa hadapan. Pengukuran kualiti guru mempunyai perkaitan yang signifikan dengan pencapaian guru dalam memastikan kecemerlangan akademik pelajar. Guru yang berefikasi tinggi sentiasa bersikap positif dalam menangani cabaran di dalam bilik darjah mahupun di luar, sentiasa kreatif dalam mengolah suasana kesukaran kepada persekitaran pembelajaran yang menarik. Dapatan ini secara umumnya membuktikan secara statistik bahawa guru-guru sekolah menengah di Sabah mempunyai efikasi tinggi yang komited terhadap profesonal mereka.

Walaupun secara rasmi keputusan peperiksaan awam di Sabah secara kumulatif memperlihatkan keputusan yang kurang memberangsangkan berbanding negeri-negeri lain di Malaysia, namun dapatan kajian penyelidikan ini telah membuktikan guru-guru akademik tingkatan mod 1 mempunyai tahap efikasi yang tinggi. Kewujudan faktor-faktor lain yang berpotensi memberi pengaruh terhadap pencapaian akademik pelajar wajar menjadi perhatian pihak-pihak yang berkenaan. Faktor sumber manusia iaitu guru telah berbukti mempunyai kompetensi yang baik dalam menjalankan tugasan, keperluan kritikal yang perlu diimbangi adalah kewujudan faktor-faktor lain yang berada di luar kemampuan guru-guru.

\section{Hubungan di Antara Kepuasan Kerja Dengan Efikasi Guru}

Model Motivasi Kerja Dua Fakor, Herzberg (1959) menyatakan bahawa faktor hygiene atau faktor pemeliharaan menyebabkan banyak ketidakpuasan bila faktor tersebut tidak ada, tetapi memberikan motivasi jika faktor itu ada. Sebaiiknya faktor motivator membimbing ke arah motivasi yang kuat tetapi tidak menyebabkan ketidakpuasan jika faktor tersebut tidak ada. Teori Kepuasan Kerja Dua Faktor oleh Herzberg yang menyatakan bahawa prestasi kerja yang tinggi menghasilkan kepuasan kerja. Antara dua faktor yang meningkatkan motivasi pekerja ialah faktor kesihatan (hygience) dan faktor pertumbuhan (growth). Dalam usaha sesebuah organisasi meningkatkan produktiviti, kepuasan kerja perlu ditingkatkan terlebih dahulu kerana sekiranya kakitangan gembira dalam bekerja, tahap efisyen yang tinggi akan dapat dicapai. Kebanyakan individu yang bekerja memperuntukkan masa yang panjangdi tempat kerja, jadi ketidakpuasan kerja sudah tentu banyak mempengaruhi emosi dan kebahagiaan hidup dalam seharian (Lanner, 2010)

\section{Pengaruh Kepuasan Kerja Terhadap Efikasi Guru}

Kepuasan kerja guru menjadi satu indikator penting untuk menjamin kesejahteraan guru dan pelajar-pelajar yang diajar. Peningkatan kepuasan kerja mendorong kepada pengekalan 
jawatan dan dapat menghasilkan guru yang berkualiti. Kajian tentang efikasi guru pada era ini dilihat semakin menarik terutamanya dalam penglibatan mereka secara langsung sama ada dalam memperkasakan aktiviti pengajaran dan pembelajaran atau tingkah laku dalam profesion perguruan (Yilmiz, 2011; Fatma Alkan dan Emine, 2012; Mustafa Ugras et al., 2012). Tschannen dan Hoy (2001) bersetuju bahawa efikasi guru terbukti mempunyai hubungan kuat terhadap banyak pencapaian pendidikan yang bermakna seperti kegigihan, semangat, komitmen dan tingkah laku pengajaran, pencapaian murid, motivasi, dan kepercayaan efikasi kendiri. Hal ini adalah kerana efikasi guru mempunyai perkaitan dengan tingkah laku mereka dalam kelas dan mempunyai kesan terhadap usaha, matlamat, aspirasi serta bagaimana mereka berhadapan dengan halangan (Tschannen dan Hoy, 2002). Keupayaan dan keyakinan tinggi menjadi pemangkin kepada keberkesanan pengajaran guru terutamanya terhadap pembelajaran pelajar. Hal ini adalah kerana guru yang berkecenderungan komited dalam pengajaran sentiasa bermotivasi dan bersunggih-sungguh ingin meningkatkan pencapaian prestasi yang lebih baik. Dalam konteks kajian ini, analisis terperinci perbandingan skor min antara variabel tahap efikasi guru adalah lebih tinggi serta mendominasi variabel lain.

\section{Kesimpulan}

Dapatan kajian ini memberi beberapa implikasi penting terhadap pengurusan organisasi pendidikan dalam usaha meningkatkan dan mengekalkan tahap kepuasan kerja dalam kalangan guru akademik tingkatan enam di Pantai Barat Sabah. Walaupun dapatan kajian menunjukkan tidak terdapat perbezaan yang signifikan dalam kepuasan kerja dan iklim sekolah dalam guru akademik tingkatan enam. Namun aspek kepuasan kerja masih lagi menjadi elemen penting dalam menentukan sumbangan pekerja kepada organisasi. Insentif dan keperluan fasiliti untuk guru-guru akademik tingkatan enam perlu diberikan perhatian serius oleh pihak bertanggungjawab memandangkan keperluan pengajaran dan pembelajaran tingkatan enam adalah lebih mencabar berbanding dengan pembelajaran peringkat rendah atau menengah. Dapatan kepuasan kerja dalam kajian ini jelas memberikan impak yang besar terhadap guruguru dan keseluruhan sistem organisasi sekolah. Di samping itu, peranan pentadbir sekolah amat signifikan sebagai penggerak utama untuk memotivasi komitmen guru-guru terhadap tugasan seterusnya memastikan kepuasan kerja sekolah berkekalan.

Dapatan kajian menunjukkan guru-guru yang bekerja dalam persekitaran yang berkongsi matlamat dan keutamaan yang jelas, guru-guru yang bersikap terbuka terhadap pemerhatian oleh rakan-rakan sekerja akan berasa lebih yakin akan keupayaannya melaksanakan pelbagai strategi pengajaran. perbezaan efikasi guru turut dipengaruhi kepercayaan guru-guru terhadap keupayaan rakan-rakan sejawat. Oleh itu, salah satu implikasi terhadap amalan ialah perlunya usaha-usaha dilakukan untuk meningkatkan keupayaan guru menerusi pembangunan sekolah dan latihan dalam perkhidmatan berbanding menghantar guru-guru secara individu untuk menyertai bengkel dan kursus yang dilaksanakan di luar sekolah.

\section{Bibliografi}

Abd. Samad, R. S., \& Gooi, A. W. 2005. Hubungan antara iklim sekolah dengan kepuasan kerja guru sekolah menengah di Wilayah Persekutuan. Jurnal Pendididkan. Universiti Malaya 25: 163-178.

Abdul Rahim Abd Rashid. 2005. Profesionalisme Keguruan Prospek dan Cabaran. Dewan Bahasa dan Pustaka, Kuala Lumpur.

Abdullah, A. G. 1997. Hubungan persepsi kepimpinan transformasi dengan kepuasan dan komitmen kerja. Pulau Pinang: Universiti Sains Malaysia.

Ali Abbas. J. 1998. Decision Style and Work Satisfaction of Arab Gulf Executives: A Crossnationa Study. International Journal of Management \& Organization, 19(2): 22-37. 
Ali Turkyilmaz, Gulsen Akman, Coskun Ozkan and Zbigniew Pastuszak. 2011. Empirical study of public sector employee loyalty and satisfaction. Industrial Management \& Data Systems Journal, 111(5): 675-696.

Bandura, A. 1996. Self-efficacy in Changing Societies. New York: Cambridge Univercity Press.

Bandura, A. 1997. Self-efficacy: The Exercise of Control. New York: Freeman \& Co.

Bandura, A. 2000. Self-efficacy: The foundation of agency. In W. J. Perrig and A. Grob (Eds.), Control of human behavior, mental processes and consciousness. Mahwah, NJ: Erlbaum.

Bardi, A. and Schwartz, S. H. 2003. Values and behavior: Strength and structure of relations. Personality and Social Psychology Bulletin, 29 (10): 1207-1220.

Bhasah Abu Bakar. 2007. Kaedah Analisis Data Penyelidikan Ilmiah. Kuala Lumpur: Utusan Publications dan Distributors Sdn Bhd.

Bozman E. C. 2011. "The effects of principals' leadership styles, teacher efficacy, and teachers' trust in their principals on student achievement'. ETD Collection for Tennessee State Univercity. Dimuat naik daripada http://digitalscholarship.tnstate.edu/dissertations/AAI3368683 pada 1 Januari 2011.

Chein, H.W. 2010. The Relationship Among Leisure Paricipation, Leisure Satisfaction, And Emotional Intelligence Among Elementary School in Northern Taiwan, Doctoral Dissertation. Univercity Incarnate Word.

Chua Yan Piaw. 2006. Kaedah dan statistik penyelidikan buku 1 kaedah penyelidikan. Malaysia: Mc Graw Hill.

Chua Yan Piaw. 2009. Asas Statistik Penyelidikan: Buku 2. Kuala Lumpur: Mc Graw Hill.

Chua Yan Piaw. 2013. Kaedah Dan Statistik Penyelidikan; Asas Statistik Penyelidikan, Analisis Data Skala Likert (Edisi ke-2). Malaysia; Mc Graw Hill, Education.

Chua Yan Piaw. 2013. Kaedah Dan Statistik Penyelidikan; Asas Statistik Penyelidikan, Analisis Data Skala Likert (Edisi ke-2). Malaysia; Mc Graw Hill, Education.

Cooper, D. R. and Schlinder, P. S. 2003. Business Research Method ( $8^{\text {th }}$ edition). New York: Mc Graw Hill Bookco.

Cousin, J. B. \& Walker, C. A. 2000. Predictors of teachers' valuing of systematic inquiry in schools. Canadian Journal of Programe Evaluation (special issue), 25-53.

Dg Norizah Binti Ag Kiflee @ Dzulkifli. 2014. Kepimpinan Instruksional, Motivasi Kerja dan Prestasi Kerja Guru Mata Pelajaran Sejarah Negeri Sabah. Tesis Doktor Falsafah. Universiti Malaysia Sabah.

DiPaola, M. F. \& Tschannen-Moran, M. 2001. Organizational citizenship behavior in schools and its relationship to school climate. Journal of School Leadership, 11:424-447.

Dzukifli Sipon. 1996. Iklim Organisasi dan Perkaitannya Dengan Prestasi Kerja Pegawai Runding Perbadanan Produktiviti Negara (NPC). Kertas Projek M. Sc. UPM.

Faridah Abdullah dan Khalid Johari. 2010. Perbezaan Efikasi Guru-guru di Sekolah Menengah Teknik, Kota Kinabalu, Sabah. Kertas penyelidikan yang dibentang di International Conference on Education 2010 (ICE 10) Brunei Darulssalam. Universiti Brunei Darulssalam pada 24-27 Mei 2010.

Fatma Alkan and Emine Erdem. 2012. The relationship between teacher self-efficacy and competency perceptions of chemistry teacher candidates. Procedia-Social and Behavioral Sciences, 47: 1927-1932.

Goodman, S. H., Fandth, P. M., Michlitch, J. P., and Lewis, P. S. 2007. Management Challengers For Tomorrow's Leaders. International Students Edition. South-Western.

Hair, J. F. Black, W. C., Babin, B. J. Anderson, R. E. \& Tatham, R. L. 2006. Multivariate data analysis. New Jersey: Pearson Prentice Hall. 
Hensen, R. K. 2001. Teacher self-efficacy: Substantive implications and measurement dilemmas. A paper presented at annual meeting of the Educational Research Exchange, January 26, 2001, Texas A\&M Univercity, College Station, Texas.

Herzberg. F., Maunser, B. and Syndermen, B. B. 1959. The Motivation To Work (2 ${ }^{\text {nd }}$ edition). New York: John Wiley \& Sons.

Hoy, W. k., \& Woolfolk, A. E. 1993. Teachers' sense of efficacy and the organizational health of schools. The Elementary School Journal, 93 (4): 355-372.

Hoy, W. K., Sweetland, S. R., \& Smith, P. A. 2002. Toward an organizational model of achievement in high schools: The significance of collective efficacy. Educational Administration Quarterly. Vol. 38(77).

Hoy, WK, John Tarter, C., Robert, B., \& Kottkamp. 1991. Open school/Health school measuring organizational climate. Sage Publications.

Jain, A., Saeed, K., Arnaout, S. \& Kortum, E. 2012. The psychosocial environment at work: An assessment of the world health organization Eastern Mediterranean. Health Journal 18(4): 325-331.

Jonathan Cohen, Elizabeth M. Mccabe, Nicholas M. Michelli \& Terry Pickeral. 2009. School Climate: Research, Policy, Practice, and Teacher Education. Researchgate.net

Junaidah Mohamad dan Nik Rosila Nik Yaacob. 2013. Kajian tentang kepuasan bekerja dalam kalangan guru-guru pendidikan khas. Asia Pacific Journal of Educators and Education, 28: 103-115.

Kementerian Pendidikan Malaysia. 2012. Laporan Awal Pelan Pembangunan Pendidikan Malaysia 2013-2025. Putrajaya: Kementerian Pendidikan Malaysia.

Khalid Johari, Zurida Ismail, Shuki Osman \& Ahmad Tajuddin Othman. 2009a. Pengaruh Jantina, Pengalaman Mengajar dan Efikasi Guru ke Atas Efikasi Kolektif di Kalangan Guru Sekolah Menengah. Kertas penyelidikan yang dibentang di International Conference on Education 2009 (ICE 2009) Brunei Darussalam. Universiti Brunei Darussalam pada 23-26 Mei 2009.

Khalid Johari, Zurida Ismail, Shuki Osman \& Ahmad Tajuddin Othman. 2009b. Kesan Kelayakan Guru ke Atas Efikasi Guru di Kalangan Guru Sekolah Menengah. Kertas penyelidikan yang dibentang di International Conference on Education 2009 (ICE 2009) Brunei Darussalam. Universiti Brunei Darussalam pada 23-26 Mei 2009.

Khalid, A. 1997. Hubungan gaya kepimpinan dan gaya kepempinan transformasi pengetua dengan kepuasan dan motivasi. Universiti Utara Malaysia.

Kreitner, R. \& Kinicki, A. 2007. Organizational Behavior. New York: McGraw Hill.

Krejcie, R. V. 1970. Determing sample size for research activities. Educational and Psychological, 30: 607-610.

Lanner, M. (2010). Contributing Factors To Teacher Satisfaction For Jewish Day School Educators. UMI Dissertations Publishing: Yeshiva University.

Lay Yoon Fah. 2008. Pengenalan kepada analisis statistik dalam penyelidikan sains sosial. Selangor Darul Ehsan: Venton Publishing.

Maistry, S. M. \& Parker, K. 2010. Teacher efficacy : An investigation of Economics teachers. Africa Education Review, Vol. 7, \&, (2), 45-53.

Maisura M. Yusof. 2007. Iklim Organisasi dan Hubungannya dengan Gelagat Kewarganegaraan Organisasi di Kalangan Guru-Guru Sekolah Menengah Daerah Pontian Johor. Skudai, Johor: Universiti Teknologi Malaysia.

Maslow, A. H. 1943. "A Theory of Motivation." Psychological Review, 50(4): 370-396.

Meyer, J. ,. 1990. Affective and continuance commitment to the organization: Evaluation of measures analysis of concurrent and time-lagged relations. Journal of Applied Psyhology, 75: 710-720. 
Meyer, J. A. 1991. A three-component conceptualization of organizational commitment. Human Resource Management Review, 1: 61-89.

Mohd Majib Konting. 2004. Kaedah penyelidikan pendidikan. Kuala Lumpur: Dewan Bahasa dan Pustaka.

Mohd Majid Konting. 1993. Kaedah Penyelidikan. Kuala Lumpur: Dewan Bahasa dan Pustaka.

Mustafa Ugras, Kemalettin Ay, Seda Altunbas, and Erol Cil. 2012. Examining of teacher candidates' attitudes to science teaching and self efficacy related to alternative measurement assessment. Social and Behavioral Sciences, 47: 1457-1461.

Narahan Bin Raduan. 2016. Pengaruh Tingkah Laku Kepimpinan Instruksional, Kepuasan Kerja, Kecerdasan Emosi dan Efikasi Guru Terhadap Komitmen Organisasi Dalam Kalangan Guru Sekolah New Deal di Negeri Sarawak. Ph.D. Thesis. Universiti Malaysia Sabah, Kota Kinabalu, Sabah.

Narahan Bin Raduan. 2016. Pengaruh Tingkahlaku Kepimpinan Instruksional, Kepuasan Kerja, Kecerdasan Emosi dan Efikasi Guru Terhadap Komitmen Organisasi Dalam Kalangan Guru Sekolah New Deal Di Negeri Sarawak. Tesis PHD. Universiti Malaysia Sabah.

Noor, N. H. (n.d.). Evaluating the psyhometric properties of Allen and Mayer's organizational commitment scale: A cross cultural application among Malaysian academic librarian. Malaysia Journal of Library \& Information Science, 11: 89-101.

NoorHafeza Herliani Binti Adey. 2015. Hubungan antara kecerdasan emosi dengan kepuasan kerja dan komitmen organisasi dalam kalangan guru di sekolah menengah. Disertai Sarjana. Universiti Malaysia Sabah.

Nor Mohamad Zulhairi Ismail, Jamalul Lail Abdul Wahab dan Ruzita Md Hassan. 2016. Kepuasan Kerja Guru dan Perbezaannya Berdasarkan Pencapaian Sekolah. Jurnal Personalia Pelajar 19(1): 49-54.

Otham Bin Md Johan \& Siow Set Fun. 2011. Hubungan Antara Stres Dengan Kepuasan Kerja Guru Penolong Kanan Di Sekolah Jenis Kebangsaan Cina Daerah Kulai. Journal of Science \& Mathematics Education. 1-9.

Pashiardi, G. 2000. School climate in elementary and secondary school: views of cypriotprincipals and teachers. The International Journal of Educational Management, 14 (5): 224-237.

Prabagaran A/L Raghavan. 1998. Iklim Organisasi Dan Perkaitannya Dengan Prestasi Kerja Guru Sekolah Menengah Di Ampang. Tesis Ijazah Sarjana. Universiti Putra Malaysia.

Quanglia, R., \& Marion, s. 1991. The relationship of teacher satisfaction to perceptions of school organization, teacher empowerment, work conditions and community status. Education, 112(2): 206-222.

Rahmah Murshidi, Mohd Majid Konting, Habubah Elias \& Fooi, F. S. 2006. Sense of efficacy Among Beginning Teachers in Sarawak. Teaching Education 17(3): 265-275.

Rahmah Murshidi. 2005. Factors Associated With Sense Of Efficacy Among First Year Teachers in Sarawak. Tesis PHD. Universiti Putra Malaysia.

Ratna Dewi Bachria \& Asmadi Alsa. 2015. Iklim Sekolah dan Dukungan Sosial Guru Matematika sebagai Prediktor Keberhasilan Prestasi Belajar Matematik Siswa SMA. Gadjah Mada Journal Of Psychology, Volume 1, No. 3: 129-139.

Sayudi, I. B. 2014. Hubungan antara gaya kepimpinan transformasi pengetua dengan kepuasan kerja guru-guru sekolah menengah kebangsaan di Wilayah Persekutian Labuan. Disertasi Sarjana. Universiti Malaysia Sabah.

Sekaran, U. 2004. Research Methods for Business. A Skill Building Approach. John and Wiley Inc.: USA. 
Sekaran, U. and Bougie, R. 2010. Research Methods For Business; A Skill Building Approach ( $5^{\text {th }}$ edition). New York, United Kingdom: John Wiley \& Sons Inc.

Sergiovanni, T. J. 1992. Moral leadership: Getting to the heart of school improvement. San Francisco: Jossey-Bass.

Sheridan, J.C. 2013. SPSS Version 20.0 for Windows: Analysis without Anguish. Australia: John Wiley \& The Sons Australia Ltd.

Spector, P. 1997. Job Satisfaction : Application, Assesment, Cause and Consequences. California: Sage.

Tabachnick, b., \& Fidell, L. 2001. Using multivariate statistics (5 $5^{\text {th }}$ ed.). Boston: Pearson Education.

Tan, S. L. 2010. Job Statisfaction Survey Malay Translation [electric version]. Retrieved from http://www.shell.cas.usfedu/jsstranslate.html.

Taylor, D. L., \& Tashakkori, A. 1995. Decision participation and school climate as predictors of job satisfaction and teacher's sense of efficacy. Journal of Experimental Education, 63(3): 217-227.

Teng L. K. 2006. Pengaruh Faktor Terpilih Terhadap Efikasi Kendiri Guru Sekolah Menengah di Negeri Sarawak. Thesis Doktor Falsafah UPM.

Tschannen-Moran, M. and Woolfolk Hoy, A. 2002. The influence of resources and supoort on teacher's efficacy beliefs. (Electronic version) Paper presented at the annual meeting of the American Educational Research Association, April 2. New Orleans, LA.

Tschannen-Moran, M., Parish, J. \& DiPaola. M. F. 2006 School climate and state standards: How interpersonal relationships influence student achievement. Journal of School Leadership, 16: 386-415.

Tschannen-Moran, M., Woolfolk Hoy, A. 2001. Teacher efficacy: Capturing an elusive construct. Teaching and Teacher Education, 17 (17): 202-248.

Tschannen-Moran, M., Woolfolk, A. \& Hoy, W. K. 1998. Teacher efficacy: Its Meaning and Measure. Review of Education Reaserch, 68: 202-248.

Waruwu Binahati. 2015. The Correlation between Teachers' Perceptions about Principal's Emotional Intelegence and Organizational Climate and Job Satisfaction of Teachers of State Senior High School in Gunungsitoli Nias, Indonesia. Journal of Education and Practice. ISSN 2222-288X Vol. 6, No. 13

Weiss, H. M. 2002. Descontructing job satisfaction: Separating evaluations, beliefs and affective experiences. Human Resource Management Review, 12: 173-194.

Wookfolk-Hoy, A., \& Spero, R. B. 2005. Changes in teacher efficacy during the early years of teaching. A comparison of four measures. Teaching and Teacher Education, 21: 343356.

Woolfolk-Hoy, A. 2001. Educational psychologu ( $8^{\text {th }}$ ed). Boston: Allyn \& Bacon.

Woolfolk, A. E., \& Hoy, W. K. 1990. Prospective teachers' sense of efficacy and beliefs about control. Journal of Educational Psychology. Vol. 82: 81-91.

Yilmiz, Cevdet. 2011. Teachers' Perception of Self-Efficacy, English Proficiency, and Instructional Strategies. Social Behavior and Personality, 39(1): 91-100. 